\title{
認定医症例報告
}

相反性クリックを有する無歯顎顎関節症患者に対し

全部床義歯製作により治療した 1 症例

王丸 寛美

\section{A Case Report of Treatment by Complete Dentures \\ for a Patient with Reciprocal Clicking}

Ohmaru Tomomi

\begin{abstract}
抄 録
症例の概要：全部床義歯の長期使用および片側咀嚼による咬合高径の低下と下顎偏位を原因とした，関 節円板前方転位症例に対し，義歯製作の咬合採得時に円板の復位を試み，上下䪽全部床義歯を製作し た.

考察：本来は旧義歯による治療澦位への適応を試みるべきであり，また，関節円板の転位程度が大きい 場合や変形が著しい場合には下顎位の修正は難しく, 高齢患者では新顎位に対する適応能力にも限界が あると考える. 本症例は円板転位が軽度で, 新顎位での適応能力が大であったため, 義歯製作時の下顎 位の修正によって円板の復位が可能であったものと考える。

結論：新義歯装着によりクリックは消失し, MRI 所見から円板の復位が確認され, 患者の新顎位への 適応も認められた。
\end{abstract}

和文キーワード

顎関節症，相反性クリック，フランジテクニック，全部床義歯

\section{I. 緒 言}

全部床義歯の長期使用および片側咀嚼による咬合高 径の低下と下顎位の偏位が原因で, 関節円板の前方転 位が生じた症例に対し，円板が復位する下顎位で咬合 採得を行い，上下顎全部床義歯を製作した。治療方法 として，まず旧義歯による治療顎位への適応を試みる べきであるが, 患者の強い要望により, 新義歯での適 応を試みた。

\section{II. 症例の概要}

患 者：68 歳，女性.
初診日: 平成 11 年 7 月 19 日.

主 訴: 左側顎関節の雑音.

現病歴: 1 カ月ほど前より, 左側の顎にガクガクと 雑音が生じ始めたが, それに伴う疼痛は認められな かった. 患者は 4 年前にも同様の症状を認めたことが あり, 当時は本学口腔外科を受診したところ, 経過観 察を行うよう指示され, 放置していたら雑音は消失し た. 今回は改善が認められないため, 再度, 本学口腔 外科を受診, 義歯の精査を目的として顎関節症科を院 内紹介され，当科を受診した。

現 症: 触診の結果より両側の咬筋, 側頭筋, 顎二 腹筋, 胸鎖乳突筋および関節包に圧痛は認められな かった. 関節雑音は左側顎関節部において開口時 17 $\mathrm{mm}$, 閉口時 $15 \mathrm{~mm}$ でクリックを認め, それに伴う

九州歯科大学歯科補経学第 1 講座

Department of Removable Prosthodontics, Kyushu Dental College

受付：2004 年 6 月 14 日/受理：2004 年 10 月 8 日

Received on June 14, 2004/Accepted on October 8, 2004 
顎運動の偏位が認められた．最大開口量は $40 \mathrm{~mm}$ で あった。

レントゲン所見：パントモグラフィー, Temporomandibular joint パノラマより，左側下顎頭やや前 方に突出したオステオファイト像を認め，両側下顎頭 後方偏位が認められた。

口腔内所見：著しい下頡顎堤吸収と上下顎全部床義 歯人工歯の咬耗による咬合高径の低下が認められた。

MRI 所見：左側顎関節において閉口時の下顎頭後 上方偏位に伴う，関節円板の前方転位を認めたが，開 口時には円板の復位が認められた。

\section{1. 診断}

全部床義歯の長期使用および片側咀嚼による咬合高 径の低下と下顎位の偏位が原因で，関節円板の前方転 位が生じた症例であり，日本顎関節学会分類に従い， 左側顎関節症IIIa 型およびIV型と診断した。

\section{2. 治療方針}

左側関節円板は復位可能であり，関節円板を整位さ せることを目的とした上下顎全部床義歯の製作を行う こととした。

患者は同年 3 月に他院にて義歯の新製を行ったもの の，疼痛が生じたため使用せず，旧義歯を現在まで 10 年近く使用していたため, 新義歯は 9 月以降に装 着を行えるように義歯の製作を開始する予定とした。 その間，現在使用している義歯は咀嚼に問題もなく， 疼痛が生じることもないため，このまま使用したいと いう患者の希望をふまえ，新義歯完成までの期間は現 在の義歯を使用してもらい，新義歯にて新しい顎位へ の適応を試みることにした。

\section{III. 治療内容と経過}

研究用模型を製作後，顎堤の診査を行い，個人卜 レーを製作，辺縁形成を行った。辺緑形成を行うこと で義歯周囲に付着する筋，軟組織の機能状態に適した 形態を記録し，辺縁封鎖性を高め，義歯への脱離作用 を可及的に少なくすることができる.

上下䪽個人トレーの辺緑形成を行った後, 精密印象 を行った。今回は精密印象法として閉口印象法を用い た。この方法は印象時に粘膜に対して一方向から平等
に機能圧をかけることができ，閉口時の咬筋の収縮状 態を印象辺縁に取り入れることができる。

製作した作業用模型上にトレー用レジンで咬合床を 製作したが，その際に硬化時の変形を補正するため, 咬合床内面を作業用模型上でリライニングし，より適 合性を高めた。

患者は長期にわたる片側咀嚼により，下顎位の片側 的偏位が生じていたため，全部床義歯製作過程の咬合 採得時に，相反性クリックの治療顎位を求める要領 で，患者に大開口を指示した後，やや前方位を取らせ ながらゆっくりと閉口させていき，閉口時クリックが 生じる直前の顎位を採得した。旧義歯咬合時と比較す ると, 約 $2 \mathrm{~mm}$ 下顎前方位で, 左側の咬合高径が約 3 $\mathrm{mm}$ 挙上された状態となった.この状態は，右側の下 顎頭を中心として，左側の下顎頭が前下内方へ回転し た状態であり，これによって左側関節円板が復位した 状態での下䪽位を採得することができた。

当科では全部床義歯の維持安定をより良好にするた めにフランジテクニックを用いている．フランジテク ニックを用いることによって，デンチャースペースに おける煩圧，口唇圧，舌圧が相互にバランスのとれた 筋圧等圧区域内に義歯を納め，筋圧による義歯の脱離 作用を減少させ，維持安定を増強させることができ る ${ }^{11}$. 特に今回は，治療顎位における義歯製作を行う ため，患者が治療顎位での咬合時に義歯が十分に維持 安定していることが重要であると考え，フランジテク ニックを用いた。

術式は, 咬合採得後, 咬合高径保持装置を付与した 後, 上顎 6 前歯の審美性を口腔内で確認した。次に下 顎咬合床にソフトプレートワックスを築盛し, 口腔内 で機能運動をさせることで，スペースを構成するロ 唇, 煩, 舌, 口腔底の諸筋の機能状態をワックスに記 録することができた。口腔内での維持・安定を確認後 に，下顎咬合床を作業模型上に戻し，デンチャース ペース石膏コアーを製作した。

石膏コアー内のスペースに人工歯を排列する際に は，前歯部では上顎前歯部との審美性を考慮し排列を 行った。的歯部はスペース内のやや舌側寄りに排列を 行った.これは, 当科の以前の研究からスペース内で も舌側寄りに排列を行うことでより安定性が高まると いう報告を参考にしている，上顎臼歯部は下頡臼歯部 と咬合させて排列を行い，中心咬合位での早期接触を 


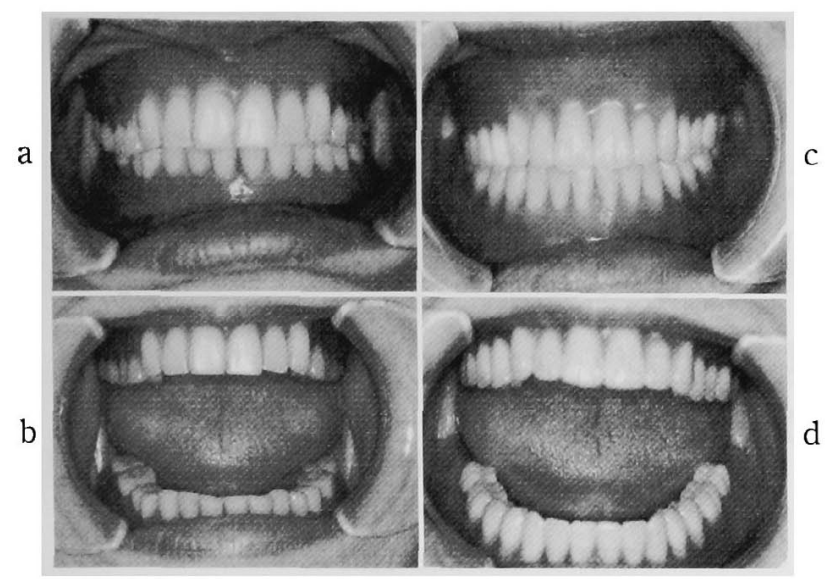

図 1 Comparison of intraoral condition

$\mathrm{a}, \mathrm{b}$ : Closing and opening mouth with old denture $\mathrm{c}, \mathrm{d}$ : Closing and opening mouth with new denture 口腔内状態の比較

$a, b$ : 旧義歯装着時の開口時，開口時

$\mathrm{c}, \mathrm{d}$ : 新義歯装着時の閉口時, 開口時

除去しておいた.

再度口腔内で試適を行い, ソフトプレートワックス を用いて機能的歯肉形成を行うことで，さらに維持・ 安定性を高めた。

重合前に上顎のテンチのコアーを採得し，重合後， そのコアーを用いて上下顎義歯を再付着した．再付着 後, 中心咬合位, 左右側方運動位, 前方運動位での早 期接触を除去し，最後にラッピングペーストを咬合面 上にのせ，自動削合を行った。

新義歯と旧義歯を比較すると，新義歯では床面積が 広くなり，歯列弓もやや拡大し，舌房も改善された。 口腔内の状態を比較すると（図 1), 咬合高径の改善 が認められ，良好な維持・安定性が確認された。

顎関節と関節円板の比較を行うと（図 2), 旧義歯 装着時の左側䫇関節において閉口時に関節円板の前方 転位が認められたが，新義㐘装着時には閉口時の関節 円板が復位した状態を確認することができた。

顎運動を比較すると（図 3)，旧義歯装着時には開 口時 $17 \mathrm{~mm}$, 閉口時 $15 \mathrm{~mm}$ でクリックを認め, それ に伴う顎運動の偏位が認められていたが，新義歯装着 時には相反性クリックは消失し, 顎運動も直線性を示 した。

新義歯装着直後, 患者は新たな顎位に違和感を示し たものの, 調整 2 回目の来院時には適応が認められ, 咀嚼や発音に対する問題は消失していた。

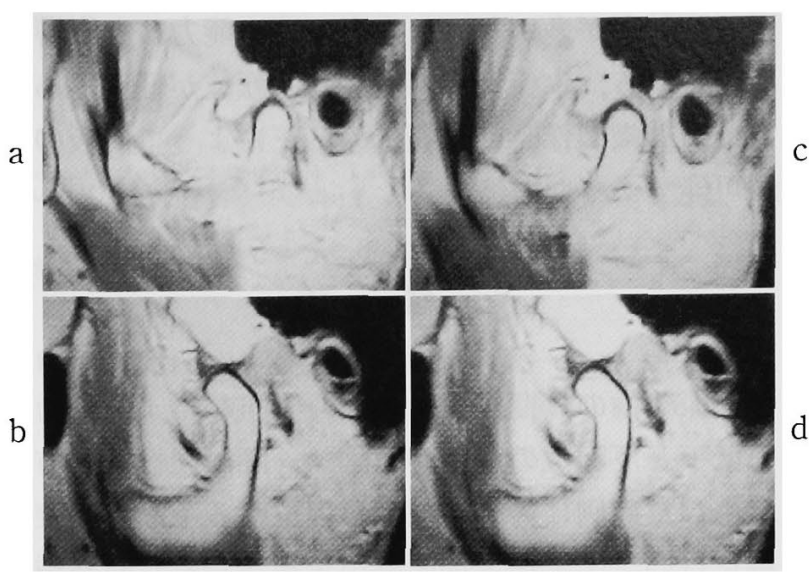

図 2 Comparison of temporomandibular joint, disc (Left side)

$\mathrm{a}, \mathrm{b}$ : Closing and opening mouth with old denture $c, d$ : Closing and opening mouth with new denture 䫟関節・関節円板の比較（左側）

$a, b$ : 旧義歯装着時の閉口時, 開口時

$\mathrm{c}, \mathrm{d}$ : 新義歯装着時の閉口時, 開口時

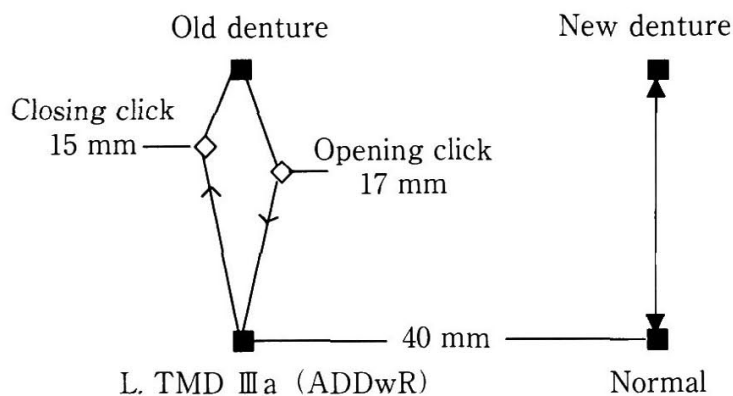

Reciprocal click

図 3 Comparison of mandibular movement 顎運動の比較

\section{IV. 考察}

本症例では, 治療過程に扔いて, 本来ならば治療買 位で旧義歯の調整を行い, 新しい顎位での適応を先に 試みるべきであるが，今回は旧義歯装着時に疼痛もな く, クリック以外の問題がないためこのまま使用した いという患者の希望もあり, 新義歯による新しい顎位 への適応を試みた。また，下顎頭の形態異常に対して も, 症状が認められなかったため, 積極的な加療は行 わなかった。

関節円板の転位程度が大きい場合は，下顎位の修正 量が大きくなるため，下顎位の修正による円板の整位 は難しいと考える。また，円板の変形が著しい場合に も, 下顎位の修正は難しく, さらに, 全部床義歯装着 
患者は高齢者が多いため，患者の適応能力にも影響さ れると考える．本症例は円板の前方転位が軽度であっ たため, 義歯製作時の下顎位の修正によって円板の復 位が可能であったと考える.

\section{V. 結 論}

全部床義歯の長期使用および片側咀嚼による咬合高 径の低下と下顎位の偏位が原因で，関節円板の前方転 位が生じた症例に対し，円板が復位する下顎位で咬合 採得を行い，上下顎全部床義歯を製作した．新義歯装 着によりクリックは消失し, MRI 所見から円板の整 位が確認され，患者の新しい顎位への適応も認められ た。新義歯装着後 3 年経過しているが, 患者は現在も
顎関節症症状および義歯ともに問題なく経過観察を 行っている.

\section{文献}

1） 豊田静夫, 守川雅男. コンプリートデンチャー その考 え方と臨床 231-306, 東京：クインテッセンス出版, 1994.

著者連絡先：王丸 寛美

T803-8580＼cjkstart福岡県北九州市小倉北区真鶴 2-6-1

TEL : 093-582-1131

FAX : 093-582-1139

E-mail : t-ohmaru@kyu-dent.ac.jp

\title{
A Case Report of Treatment by Complete Dentures for a Patient with Reciprocal Clicking
}

\author{
Ohmaru Tomomi \\ Department of Removable Prosthodontics, Kyushu Dental College
}

J Jpn Prosthodont Soc 48: 815-818, 2004

\section{ABSTRACT}

Patient: This case report describes a treatment method for a 68-year-old female with reciprocal clicking on her left temporomandibular joint. Wearing complete dentures for a long time and her unilateral habitual mastication caused this condition. As a countermeasure, an interocclusal record was taken at a position without clicking and a new complete denture set was fabricated.

Discussion : In such a case, we usually expect to adopt a new jaw position by adjusting the old dentures. If the degree of disc displacement or transformation of the disc is severe, mandibular repositioning may be difficult. Furthermore, many aged patients have limitated ability to adapt to a new mandibular position. In this case, the degree of disc displacement was slight, so the patient could accept a new position.

Conclusion : After wearing the new dentures, her clicking disappeared and MRI showed reduction of the disc. She was able to accept the new position.

\section{Key words}

temporomandibular disorders, reciprocal clicking, flange technique, complete denture 